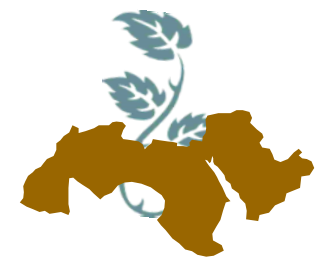

\title{
HETEROSIS AND COMBINING ABILITY OF SOME BREAD WHEAT GENOTYPES
}

\author{
Hassan $^{1}$, A.M.; M.F. Ahmed ${ }^{1}$ and M.A. Rashed ${ }^{2}$ \\ 1- Agronomy Dept., Fac. of Agric., Ain Shams Univ., Cairo, Egypt \\ 2- Genetics Dept., Fac. of Agric., Ain Shams Univ., Cairo, Egypt
}

Keywords: Wheat, Combining ability, Heterosis, Diallel crosses

\section{ABSTRACT}

Twenty one wheat hybrids and their seven parental genotypes were evaluated in the research farm of the Faculty of Agriculture 'Ain shams University, Shoubra El-khema, Cairo, Egypt, in 2016/2017 growing season. The genetic analysis was conducted using Griffing) 1956 (Method 2, model 1).

Significant differences among parent genotypes and their 21 crosses for all the studied traits (days to $50 \%$ heading, days to maturity, flag leaf area, plant height, number of spikes/ plant, spike length, number of spikelets/ spike, number of kernels/ spike, 1000-kernel weight and grain yield/ plant) were detected. This indicated that, variability exists among these populations may increase the chance appearance of good new combination that can be isolated in the succeeding generations. Parents versus crosses mean squares as an indication for average heterosis over all crosses were significant for all studied traits.

Mean squares of general (GCA) and specific (SCA) combining abilities were significant for all studied traits except spike length trait for SCA which was insignificant. GCA/SCA ratios were more than unity for all studied traits, which indicating that the additive type of gene action is of great importance in the inheritance of these traits. Heterosis over the better parents showed that, the best hybrids were Gemmiza 9xGiza 168, Sakha 93x Giza, 168, Sakha 94x Jawahir-14, Sakha 94x Bob white, Giza 168xAcsad 925 and Jawahir-14x Bob white for grain yield/ plant trait and some of the other studied traits. The best general combiner parents were Sakha 94, Jawahir-14 and Bob white for grain yield/ plant trait and some of the other studied traits. The best SCA hybrids were Gemmiza 9x Sakha 93, Gemmiza 9x Giza 168, Sakha 93x Jawahir-14, Sakha 94xJawahir-14, Sakha 94x Acsad 925, Sakha 94xBob white, Giza 168x Jawahir-14, Giza 168x Acsad 925, Jawahir-14x Bob white and Acsad 925x Bob white for grain yield/ plant trait and some of the other studied traits. These result could be used in wheat breeding programs.

Wheat (Triticum aestivum L.) is one of the leading cereals and staple food in many countries of the world including Egypt. It plays a remarkable role in meeting the food requirements of the country [Barutcular et al 2017; Ljubičić et al 2017; Singh, S.P. and V. Sharma, 2017; Thomas et al 2017 and Tiwari et al 2017].

In Egypt, wheat is the main winter cereal crop used as a staple food for urban and rural societies and the major source of straw for animal feeding [Ismail 2015, Hamda and Ibrahim 2016 and Kandil et al 2016]. However, total wheat consumption has increased drastically due to over population growth by about $2.5 \%$ per year. Egypt imports about $45 \%$ of its wheat requirements. This reflects the size of the problem and the efforts needed to increase wheat production. Thus, increasing production per unit area appears to be one of the important factors for narrowing the gap between wheat production and consumption.

Information regarding general and specific combining ability of wheat genotypes is a prerequisite to launch a successful wheat-breeding programs. Diallel mating design has been extensively used to analyze the combining ability effects of wheat genotypes and also to provide information regarding genetic mechanisms controlling grain yield and other traits. Knowledge of general and specific combining ability. influencing yield and its 
components has become increasingly important for plant breeders in the choice of suitable parents for developing potential possessing varieties in wheat. Many researchers gave reviews, which revealed that both general and specific combining ability were involved in the improvement of yield and its contributing traits in wheat such as [Tiwari et al 2017; Patel, 2017; Ljubičić et al 2017; Kumar et al 2017 and Ahmad et al 2017].

\section{The objective of the present investigation is to}

Estimate heterosis and combining abilities (GCA and SCA) as basis of improving wheat to identify the best parental genotypes and hybrids that could be used in breeding programs.

\section{MATERIALS AND METHODS}

The present study was carried out in the Research Farm, Fac. of Agric., Ain Shams Univ., Shoubra El-khema,Cairo, Egypt, during the period from 2016 to 2017, in order to evaluate the genetic performance of seven varieties of bread wheat and their $F_{1}$ hybrids in the field for some agronomic traits. The seven wheat varieties (Triticum aestivum L.) namely; (P1) Gemmiza 9, (P2) Shakha93, (P3) Sakha 94, (P4) Giza 168, (P5) Jawahir-14, (P6) Acsad 925 and (P7) Bob white and their $21 F_{1}$ hybrids (half diallel crosses) were obtained from the Professor Mohamed Abd-El Salam Rashed Prof. of Genetic, Department of Genetic, Faculty of Agriculture, Ain shams university. The varieties names, origins and pedigree are shown in Table (1).

Table 1. Names, pedigree and origins of used wheat genotypes

\begin{tabular}{|c|c|c|c|}
\hline No & Genotype & Pedigree & Origin \\
\hline $\mathrm{P} 1$ & Gemmiza 9 & $\begin{array}{l}\text { Ald"s"/Huac"Is"//CMH74A.630/5x } \quad \text { CGM.4583- } \\
\text { 5GM-1GM-0GM }\end{array}$ & Egypt \\
\hline P2 & Sakha 93 & Sakha 92/ TR810328 S8871-1S-2S-1S-0S & Egypt \\
\hline P3 & Sakha 94 & $\begin{array}{l}\text { OPATA / RAYON // KAUZ CMBW90Y3180- } \\
\text { OTOPM-3Y-010M-010M-010Y-10M-015Y-0Y- } \\
\text { OAP-0S }\end{array}$ & Egypt \\
\hline P4 & Giza 168 & MIL/Buc//Seri CM 93046-8M-04-0M-2Y-0B & Egypt \\
\hline P5 & Jawahir-14 & SHUHA-4//NS732/HER & ICARDA \\
\hline P6 & Acsad 925 & $\begin{array}{l}\text { GEN/3/GOV/AZ//MUS(s)/4/Sannine/Ald(s) ACS- } \\
\text { W-9174-10IZ-5IZ-3IZ-0IZ }\end{array}$ & Syria \\
\hline P7 & Bob white & $\mathrm{AU} / / \mathrm{KAL} / \mathrm{BB} / 3 / \mathrm{WOP}$ & CIMMYT \\
\hline
\end{tabular}

In the 2016/2017 growing season the seeds of the parents and their $21 \mathrm{~F} 1$ hybrids were planted at 15 November 2016 in a randomized complete blocks design (RCBD) with 3 replicates. The experimental plot was one row. Each row was $3 \mathrm{~m}$ in length and $25 \mathrm{~cm}$ in width. Seeds were spaced at $15 \mathrm{~cm}$ within rows, where one plant was left per the hill. There was no previous crop in the summer of 2016. The recommended cultural practices for wheat production were applied throughout the growth period. days to $50 \%$ heading, days to maturity, flag leaf area $\left(\mathrm{cm}^{2}\right)$, plant height $(\mathrm{cm})$, number of spikes / plant, spike length $(\mathrm{cm})$, number of spikelets per spike, Number of kernels /spike, 1000 grain weight $(\mathrm{g})$ and grain yield /plant $(\mathrm{g})$ traits were recorded on a sample of 10 guarded plants of each plot. Estimates of combining ability effects were made estimated by applying Griffing (1956), Method 2 model 1 (one set of $F_{1}$ 's and parents). Percentage of heterosis relative to better parent was estimated.

\section{RESULTS AND DISCUSSION}

\section{Analysis of variance}

The analysis of variance estimates for all the studied traits are shown in Table (2). The mean squares for genotypes, parents and crosses exhibited highly significant differences for all studied traits. This result indicated that variability exists among this populations may increase the chance appearance of good new combinations that can be isolated in the succeeding generations. Parents 
Table 2. Analysis of variance estimates for all studied traits in the seven parents and their half diallel crosses

\begin{tabular}{|l|c|c|c|c|c|c|}
\hline \multicolumn{1}{|c|}{ S.O.V. } & d.f & $\begin{array}{c}\text { Days to } \\
\mathbf{5 0 \%} \\
\text { heading }\end{array}$ & $\begin{array}{c}\text { Days to } \\
\text { maturity }\end{array}$ & $\begin{array}{c}\text { Flag leaf } \\
\text { area }\end{array}$ & $\begin{array}{c}\text { Plant } \\
\text { height }\end{array}$ & $\begin{array}{c}\text { No. of } \\
\text { spikes/plant }\end{array}$ \\
\hline Replications & 2 & 0.44 & 0.58 & 1.05 & 0.42 & 0.46 \\
Genotypes & 27 & $37.19^{* *}$ & $28.4^{* *}$ & $96.48^{* *}$ & $164.86^{* *}$ & $12.42^{* *}$ \\
Parent & 6 & $93.30^{* *}$ & $52.52^{* *}$ & $182.46^{* *}$ & $385.94^{\star *}$ & $24.31^{* *}$ \\
Cross & 20 & $22.04^{* *}$ & $20.79^{* *}$ & $66.94^{* *}$ & $106.25^{* *}$ & $9.28^{* *}$ \\
Par.vs.cr. & 1 & $3.57^{* *}$ & $35.81^{* *}$ & $171.42^{* *}$ & $10.42^{* *}$ & $4.06^{* *}$ \\
Error & 54 & 0.24 & 0.16 & 0.53 & 0.53 & 0.32 \\
GCA & 6 & $48.34^{* *}$ & $33.09^{* *}$ & $124.48^{* *}$ & $232.57^{* *}$ & $17.27^{* *}$ \\
SCA & 21 & $2.13^{* *}$ & $2.71^{* *}$ & $5.78^{* *}$ & $4.2^{* *}$ & $0.39^{* *}$ \\
GCA/SCA & & 2.62 & 1.38 & 2.46 & 6.41 & 6.7 \\
\hline
\end{tabular}

${ }^{*},{ }^{* *}=$ Significant at $p<0.05$ and $p<0.01$ level, respectively.

Table 2. cont.

\begin{tabular}{|c|c|c|c|c|c|c|}
\hline S.O.V. & d.f & $\begin{array}{l}\text { Spike } \\
\text { length }\end{array}$ & $\begin{array}{c}\text { No. of } \\
\text { spikelets } \\
\text { per Spike }\end{array}$ & $\begin{array}{c}\text { No. of } \\
\text { kernels per } \\
\text { spike }\end{array}$ & $\begin{array}{c}1000- \\
\text { kernel } \\
\text { weight }\end{array}$ & $\begin{array}{c}\text { Grain } \\
\text { yield/plant }\end{array}$ \\
\hline Replications & 2 & 0.01 & 0.05 & 0.77 & 0.16 & 0.57 \\
\hline Genotypes & 27 & $1.41^{* *}$ & $2.86^{* *}$ & $82.63^{\star *}$ & $80.93^{\star *}$ & $167.54^{* *}$ \\
\hline Parent & 6 & $2.89^{* *}$ & $4.57^{* *}$ & $135.44^{* *}$ & $125.21^{* *}$ & $254.93^{* *}$ \\
\hline Crosses & 20 & $0.94^{* *}$ & $2.4^{\star *}$ & $64.67^{\star *}$ & $69.27^{* *}$ & $135.1^{\star *}$ \\
\hline Par.vs.cr. & 1 & $1.97^{* *}$ & $1.72^{\star \star}$ & $124.84^{* *}$ & $48.4^{\star \star}$ & $291.96^{* *}$ \\
\hline Error & 54 & 0.19 & 0.08 & 0.57 & 0.66 & 0.34 \\
\hline GCA & 6 & $1.79^{* *}$ & $3.86^{* *}$ & $106.49^{\star *}$ & $110.77^{\star *}$ & $222.59^{\star *}$ \\
\hline SCA & 21 & 0.09 & $0.12^{* *}$ & $4.99^{\star \star}$ & $3.04^{*}$ & $8.21^{\star *}$ \\
\hline GCA/SCA & & 6.89 & 4.43 & 2.46 & 4.36 & 3.05 \\
\hline
\end{tabular}

${ }^{*},{ }^{* *}=$ Significant at $p<0.05$ and $p<0.01$ level, respectively.

versus crosses mean squares as an indication for average heterosis over all crosses were significant for all studied traits. These findings were in agreements with those reported by Shehzad et al (2015); Ahmad et al (2017) and Tiwari et al (2017). The partitioning of genetic variations among parents and their crosses revealed significant differences in general (GCA) and specific (SCA) combining abilities for all studied traits except spike length trait which for SCA was not significant, indicated that both additive and non additive genetic effects were involved in the inheritance of these traits (Table 5). Similar conclusion was recorded by Kumar et al (2017); Patel et al (2017) and Tiwari et al (2017).
Comparing the relative magnitudes of GCA and SCA variances, the GCA/SCA ratios for all measured traits were more than unity. This indicates that the largest part of the total genetic variability is due to additive gene action for the all studied traits. These results were in agreement with those reported by Sadeghi et al (2012); Singh et al (2012); Attia et al (2014) and Khaled and Abd ElDayem (2014).

\section{Mean performance of wheat genotypes}

Mean values for all studied traits are presented in Tables (3 and 4). Gemmiza 9 expressed the highest mean value for flag leaf area, plant height, 
No. of kernels/spike, spike length and No. of spikelets/spike traits. Sakha 93 parent recorded the highest values for days to $50 \%$ heading, days to maturity, flag leaf area, plant height, No. of spikes/plant, spike length and No. of spikelets/spike traits. Sakha 94 parent had the best mean value for days to $50 \%$ heading, plant height, No. of kernels/spike, No. of spikelets/spike, 1000kernel weight and grain yield/plant traits. Giza 168 parent recorded the highest values for days to $50 \%$ heading, days to maturity, flag leaf area, plant height, spike length, No. of spikelets/spike and 1000-kernel weight traits. Jawahir-14 parent expressed the highest mean value for days to $50 \%$ heading, days to maturity, flag leaf area, No. of spikes/plant, No. of kernels/spike, 1000-kernel weight and grain yield/plant traits. Acsad 925 parent recorded the highest values for 1000-kernel weight traits. Bob white parent expressed the highest mean value for No. of spikes/plant, spike length and grain yield/plant traits.

Regarding hybrid mean performances, it is clear that the highest desirable values were recorded by cross of combination Gemmiza $9 \times$ Jawahir-14 for flag leaf area, plant height, spike length, No. of kernels/spike, No. of spikelets/spike and grain yield/plant traits; Sakha 93xSakha 94 for days to $50 \%$ heading, days to maturity, flag leaf area, plant height, No. of spikes/plant, No. of kernels/spike and No. of spikelets/spike traits; Sakha 93xGiza 168 for days to $50 \%$ heading, days to maturity, flag leaf area, plant height, spike length and No. of spikelets/spike traits; Sakha 93xBob white for days to $50 \%$ heading, days to maturity, flag leaf area, No. of spikes/plant and spike length traits; Sakha 94xGiza 168 for days to $50 \%$ heading, plant height, spike length, No. of spikelets/ spike and grain yield/plant traits; Sakha 94x Jawahir-14 for days to $50 \%$ heading, days to maturity, No. of spikes/plant, No. of kernels/spike, 1000kernel weight and grain yield/plant traits; Sakha $94 \times$ Bob white for days to $50 \%$ heading, No. of spikes/plant, No. of kernels/spike, spike length and grain yield/plant traits; Giza 168x Jawahir-14 for days to $50 \%$ heading, days to maturity, plant height, No. of spikes/plant, No. of kernels/spike, spike length, No. of spikelets/spike and grain yield/plant traits; Giza 168xAcsad 925 for days to $50 \%$ heading, spike length and 1000-kernel weight traits; Jawahir-14x Acsad 925 for days to maturity, 1000-kernel weight and grain yield/plant traits; and Jawahir-14xBob white for days to $50 \%$ heading, days to maturity, No. of spikes/plant, No. of kernels/spike and grain yield/plant traits.
From these results, it could be concluded that three parents (Sakha 94, Jawahir-14 and Bob white) and four crosses combinations (Sakha 93xJawahir-14, Sakha 94 xJawahir-14, Sakha 94 x Bob white and Giza 168xJawahir-14) seemed to gave the best values for the studides traits among the studied parents and their hybrids since they expressed the most desirable values for grain yield/plant trait and most of the other studied traits. The previous mentioned three parents and four crosses would prospect in bread wheat breeding and therefore may be valuable for improving seed yield via its components traits.

\section{Heterobeltiosis}

Percentage of heterosis relative to the better parent for all the studied traits are presented in Tables (5 and 6). The best hybrid values for the studides traits were Acsad 925xBob white for days to $50 \%$ heading trait, Gemmiza 9xSakha 94, Sakha 93xSakha 94, Sakha 93xGiza 168, Sakha 93xBob white, Sakha 94xAcsad 925, Sakha 94xBob white and Acsad 925xBob white for days to maturity trait, Gemmiza 9xJawahir-14, Sakha 94xBob white and Acsad 925xBob white for flag leaf area trait, Acsad 925xBob white for plant height trait, Sakha 93xGiza 168 for No. of kernels/spike trait, and Gemmiza 9xGiza 168, Sakha 93xGiza 168, Sakha 94xJawahir-14, Sakha 94xBob white, Giza 168xAcsad 925 and Jawahir$14 \times$ Bob white for grain yield / plant trait. These results were in a harmony with those obtained by Thomas et al (2017); Kalhoro et al (2015) and Ismail (2015).

\section{General (GCA) and specific (SCA) combining ability effects}

\section{I- General combining ability effects}

Estimates of GCA effects of each parental genotypes for the different studied traits are presented in Tables (7 and 8). The best general combiner parental genotypes were Sakha 93, Sakha 94, Giza 168 and Jawahir-14 parents for days to $50 \%$ heading trait, Sakha 93, Giza 168 and Jawahir-14 parents for days to maturity trait, Gemmiza 9, Sakha 93 and Giza 168 parents for flag leaf area trait, Gemmiza 9, Sakha 93, Sakha 94 and Giza 168 parents for plant height trait, Sakha 93, Sakha 94, Jawahir-14 and Bob white parents for number of spikes per plant trait, Gemmiza 9, Giza 168 
Table 3. Mean performance of the seven bread wheat parental genotypes and their $F_{1}$ crosses for days to $50 \%$ heading, days to maturity, flag leaf area, plant height and no. of spikes/plant traits

\begin{tabular}{|c|c|c|c|c|c|}
\hline Parents and Crosses & $\begin{array}{l}\text { Days to } \\
50 \% \text { heading }\end{array}$ & $\begin{array}{l}\text { Days to } \\
\text { maturity }\end{array}$ & $\begin{array}{l}\text { Flag leaf } \\
\text { area }\left(\mathrm{cm}^{2}\right)\end{array}$ & $\begin{array}{l}\text { Plant height } \\
\text { (cm) }\end{array}$ & $\begin{array}{c}\text { No. of } \\
\text { spikes/ } \\
\text { plant }\end{array}$ \\
\hline P1:Gemmiza 9 & 107.33 & 155.00 & 45.35 & 112.37 & 7.30 \\
\hline P2:Sakha 93 & 97.00 & 148.67 & 49.07 & 101.52 & 10.50 \\
\hline P3:Sakha 94 & 95.67 & 151.00 & 36.57 & 104.21 & 9.85 \\
\hline P4:Giza 168 & 93.33 & 147.67 & 43.17 & 107.21 & 8.90 \\
\hline P5:Jawahir-14 & 90.33 & 142.00 & 39.57 & 92.54 & 11.61 \\
\hline P6:Acsad 925 & 101.33 & 153.00 & 27.35 & 87.47 & 3.80 \\
\hline P7:Bob white & 99.33 & 149.67 & 31.01 & 81.00 & 12.01 \\
\hline Parents mean & 97.76 & 149.57 & 38.87 & 98.04 & 9.14 \\
\hline Gemmiza 9 x Sakha 93 & 100.33 & 151.00 & 49.66 & 108.51 & 9.01 \\
\hline Gemmiza 9 x Sakha 94 & 97.00 & 147.33 & 41.93 & 106.89 & 8.80 \\
\hline gemmiza 9 x Giza 168 & 98.33 & 149.67 & 45.76 & 108.39 & 8.37 \\
\hline Gemmiza 9 x Jawahir-14 & 101.00 & 151.67 & 46.68 & 103.21 & 9.97 \\
\hline Gemmiza 9 x Acsad 925 & 103.33 & 154.33 & 38.96 & 96.31 & 6.29 \\
\hline Gemmiza 9 x Bob white & 102.33 & 151.67 & 38.86 & 100.81 & 9.24 \\
\hline Sakha 93 x Sakha 94 & 96.33 & 146.67 & 49.25 & 103.92 & 10.15 \\
\hline Sakha 93 x Giza 168 & 95.67 & 146.33 & 48.07 & 103.82 & 9.18 \\
\hline Sakha 93 x Jawahir-14 & 92.00 & 143.33 & 47.75 & 94.91 & 10.98 \\
\hline Sakha 93x Acsad 925 & 98.67 & 149.33 & 43.02 & 91.54 & 6.73 \\
\hline Sakha 93 x Bob white & 96.67 & 147.00 & 44.55 & 92.20 & 12.22 \\
\hline Sakha 94 x Giza 168 & 95.00 & 148.00 & 41.93 & 105.81 & 9.52 \\
\hline Sakha 94 x Jawahir-14 & 95.67 & 146.00 & 38.86 & 98.49 & 11.62 \\
\hline Sakha 94 x Acsad 925 & 97.67 & 148.33 & 35.44 & 98.41 & 8.06 \\
\hline Sakha 94 x Bob white & 96.33 & 148.00 & 38.87 & 96.71 & 12.40 \\
\hline Giza 168 x Jawahir-14 & 93.67 & 145.00 & 42.21 & 100.49 & 10.90 \\
\hline Giza 168 x Acsad 925 & 96.33 & 148.00 & 42.55 & 96.36 & 8.38 \\
\hline Giza 168 x Bob white & 97.00 & 148.33 & 43.32 & 97.25 & 11.06 \\
\hline Jawahir-14 x Acsad 925 & 97.00 & 145.33 & 35.77 & 91.03 & 9.04 \\
\hline Jawahir-14 x Bob white & 95.33 & 145.00 & 39.83 & 90.14 & 12.51 \\
\hline Acsad $925 \times$ Bob white & 97.33 & 149.00 & 32.27 & 90.82 & 8.12 \\
\hline Crosses mean & 97.29 & 148.06 & 42.17 & 98.86 & 9.65 \\
\hline General mean & 97.40 & 148.44 & 41.34 & 98.65 & 9.52 \\
\hline L.S.D 5\% & 0.81 & 0.66 & 1.2 & 1.19 & 0.92 \\
\hline
\end{tabular}


Table 4. Mean performance of the seven bread wheat parental genotypes and their $F_{1}$ crosses for spike length, no.of spikelets/spike, no. of kernels/spike, 1000-kernel weight and grain yield/plant traits

\begin{tabular}{|c|c|c|c|c|c|}
\hline Parents and Crosses & $\begin{array}{l}\text { Spike length } \\
(\mathrm{cm})\end{array}$ & $\begin{array}{c}\text { No. of } \\
\text { spikelets } \\
\text { per spike }\end{array}$ & $\begin{array}{c}\text { No. of } \\
\text { kernels } \\
\text { per spike }\end{array}$ & $\begin{array}{c}\text { 1000-kernel } \\
\text { weight }(g)\end{array}$ & $\begin{array}{c}\text { Grain } \\
\text { yield/pl } \\
\text { ant }(g)\end{array}$ \\
\hline P1:Gemmiza 9 & 12.69 & 21.87 & 70.63 & 41.53 & 19.33 \\
\hline P2:Sakha 93 & 12.00 & 22.60 & 63.11 & 40.08 & 23.19 \\
\hline P3:Sakha 94 & 10.50 & 21.53 & 72.80 & 45.37 & 30.60 \\
\hline P4:Giza 168 & 13.33 & 23.00 & 61.60 & 47.14 & 21.75 \\
\hline P5:Jawahir-14 & 11.10 & 21.00 & 75.13 & 51.90 & 39.35 \\
\hline P6:Acsad 925 & 11.57 & 19.73 & 56.32 & 55.78 & 10.17 \\
\hline P7: Bob white & 12.53 & 20.00 & 65.80 & 38.00 & 27.77 \\
\hline Parents mean & 11.96 & 21.39 & 66.49 & 45.68 & 24.59 \\
\hline Gemmiza 9 x Sakha 93 & 12.84 & 22.93 & 71.88 & 41.35 & 23.16 \\
\hline Gemmiza 9 x Sakha 94 & 12.02 & 22.00 & 73.82 & 44.19 & 26.50 \\
\hline Gemmiza 9 x Giza 168 & 13.30 & 22.93 & 70.59 & 45.07 & 24.23 \\
\hline Gemmiza 9 x Jawahir-14 & 12.52 & 22.07 & 73.59 & 48.94 & 32.90 \\
\hline Gemmiza 9 x Acsad 925 & 12.53 & 21.73 & 68.68 & 46.73 & 17.93 \\
\hline Gemmiza 9 x Bob white & 12.66 & 21.07 & 71.44 & 40.91 & 24.78 \\
\hline Sakha 93 x Sakha 94 & 11.24 & 22.93 & 71.11 & 43.99 & 28.17 \\
\hline Sakha 93 x Giza 168 & 12.79 & 23.13 & 67.94 & 44.71 & 24.44 \\
\hline Sakha 93 x Jawahir-14 & 11.94 & 21.67 & 75.90 & 48.07 & 38.04 \\
\hline Sakha 93x Acsad 925 & 12.13 & 21.00 & 60.71 & 53.45 & 19.82 \\
\hline Sakha 93 x Bob white & 12.61 & 21.13 & 64.81 & 39.36 & 28.16 \\
\hline Sakha 94 x Giza 168 & 12.67 & 22.80 & 70.44 & 48.10 & 29.83 \\
\hline Sakha 94 x Jawahir-14 & 11.24 & 21.60 & 75.24 & 50.68 & 41.83 \\
\hline Sakha 94 x Acsad 925 & 11.60 & 21.60 & 67.36 & 52.40 & 25.31 \\
\hline Sakha 94 x Bob white & 12.37 & 21.13 & 71.70 & 42.86 & 35.83 \\
\hline Giza 168 x Jawahir-14 & 12.41 & 22.13 & 73.38 & 51.56 & 38.32 \\
\hline Giza 168 x Acsad 925 & 12.60 & 21.47 & 61.53 & 53.93 & 25.06 \\
\hline Giza 168 x Bob white & 13.13 & 21.87 & 63.40 & 42.59 & 26.87 \\
\hline Jawahir-14 x Acsad 925 & 12.15 & 20.07 & 66.34 & 56.02 & 30.12 \\
\hline Jawahir-14 x Bob white & 11.61 & 20.80 & 73.41 & 48.58 & 40.91 \\
\hline Acsad $925 \times$ Bob white & 12.23 & 20.07 & 62.04 & 52.72 & 24.71 \\
\hline Crosses mean & 12.31 & 21.72 & 69.30 & 47.44 & 28.90 \\
\hline General mean & 12.23 & 21.64 & 68.60 & 47.00 & 27.82 \\
\hline L.S.D 5\% & 0.72 & 0.50 & 1.23 & 1.33 & 0.96 \\
\hline
\end{tabular}


Table 5. Percentage of heterosis relative to the better parent for days to $50 \%$ heading, days to maturity, flag leaf area, plant height and no. o spikes per plant traits

\begin{tabular}{|c|c|c|c|c|c|}
\hline Crosses & $\begin{array}{l}\text { Days to } 50 \% \\
\text { heading }\end{array}$ & $\begin{array}{l}\text { Days to } \\
\text { maturity }\end{array}$ & $\begin{array}{l}\text { Flag leaf } \\
\text { area }\end{array}$ & $\begin{array}{l}\text { Plant } \\
\text { height }\end{array}$ & $\begin{array}{c}\text { No. of } \\
\text { spikes/plant }\end{array}$ \\
\hline Gemmiza 9 x Sakha 93 & $3.44^{* *}$ & $1.57^{* *}$ & 1.20 & $-3.43^{* *}$ & $-14.19^{\star *}$ \\
\hline Gemmiza 9 x Sakha 94 & $1.39^{* *}$ & $-2.43^{\star *}$ & $-7.54^{* *}$ & $-4.88^{* *}$ & $-10.66^{\star}$ \\
\hline Gemmiza 9 x Giza 168 & $5.36^{\star *}$ & $1.35^{\star *}$ & 0.89 & $-3.54^{* *}$ & -5.96 \\
\hline Gemmiza 9 x Jawahir-14 & $11.81^{* *}$ & $6.81^{* *}$ & $2.94^{*}$ & $-8.15^{\star *}$ & $-14.13^{\star *}$ \\
\hline Gemmiza 9 x Acsad 925 & $1.97^{\star *}$ & $0.87^{\star *}$ & $-14.10^{\star \star}$ & $-14.29^{\star \star}$ & $-13.88^{*}$ \\
\hline Gemmiza 9 x Bob white & $3.02^{\star *}$ & $1.34^{\star *}$ & $-14.31^{* *}$ & $-10.29^{* *}$ & $-23.07^{\star *}$ \\
\hline Sakha 93 x Sakha 94 & 0.70 & $-1.35^{\star \star}$ & 0.37 & -0.28 & -3.30 \\
\hline Sakha 93 x Giza 168 & $2.5^{\star \star}$ & $-0.9^{* *}$ & -2.04 & $-3.16^{\star *}$ & $-12.57^{*}$ \\
\hline Sakha 93 x Jawahir-14 & $1.85^{\star *}$ & $0.94^{* *}$ & $-2.69^{*}$ & $-6.51^{* *}$ & -5.40 \\
\hline Sakha 93x Acsad 925 & $1.72^{\star *}$ & $0.45^{\star}$ & $-12.33^{\star *}$ & $-9.83^{* *}$ & $-35.90^{\star *}$ \\
\hline Sakha 93 x Bob white & -0.34 & $-1.78^{* *}$ & $-9.20^{* *}$ & $-9.18^{\star *}$ & 1.80 \\
\hline Sakha 94 x Giza 168 & $1.79^{* *}$ & 0.23 & $-2.86^{*}$ & $-1.31^{*}$ & -3.38 \\
\hline Sakha 94 x Jawahir-14 & $5.9^{* *}$ & $2.82^{* *}$ & -1.80 & $-5.49^{* *}$ & 0.14 \\
\hline Sakha 94 x Acsad 925 & $2.09^{* *}$ & $-1.77^{\star *}$ & -3.10 & $-5.56^{\star *}$ & $-18.21^{\star *}$ \\
\hline Sakha 94 x Bob white & 0.70 & $-1.11^{* *}$ & $6.28^{\star *}$ & $-7.19^{* *}$ & 3.28 \\
\hline Giza 168 x Jawahir-14 & $3.69^{* *}$ & $2.11^{* *}$ & -2.23 & $-6.27^{\star *}$ & -6.06 \\
\hline Giza 168 x Acsad 925 & $3.21^{* *}$ & 0.23 & -1.43 & $-10.12^{* *}$ & -5.81 \\
\hline Giza 168 x Bob white & $3.93^{* *}$ & $0.45^{\star}$ & 0.36 & $-9.29^{\star *}$ & $-7.88^{*}$ \\
\hline Jawahir-14 x Acsad 925 & $7.38^{\star \star}$ & $2.35^{\star *}$ & $-9.60^{\star *}$ & $-1.63^{*}$ & $-22.11^{* *}$ \\
\hline Jawahir-14 x Bob white & $5.54^{* *}$ & $2.11^{* *}$ & 0.64 & $-2.59^{* *}$ & 4.22 \\
\hline Acsad $925 \times$ Bob white & $-2.01^{* *}$ & $-0.45^{*}$ & $4.07^{*}$ & $3.83^{* *}$ & $-32.40^{* *}$ \\
\hline Mean & 3.12 & 0.66 & -3.17 & -5.67 & -10.74 \\
\hline
\end{tabular}

*and ${ }^{* *}$ indicate significance at 0.05 and 0.01 probability levels, respectively 
Table 6. Percentage of heterosis relative to the better parent for spike length, no.of spikelets/spike, no. of kernels/spike, 1000-kernel weight and grain yield/plant traits

\begin{tabular}{|c|c|c|c|c|c|}
\hline Crosses & $\begin{array}{l}\text { Spike } \\
\text { length }\end{array}$ & $\begin{array}{l}\text { No. of } \\
\text { spikelets per } \\
\text { spike }\end{array}$ & $\begin{array}{l}\text { No. of kernels } \\
\text { per spike }\end{array}$ & $\begin{array}{c}\text { 1000-kernel } \\
\text { weight }\end{array}$ & $\begin{array}{c}\text { Grain } \\
\text { yield/plant }\end{array}$ \\
\hline Gemmiza 9 x Sakha 93 & 1.16 & 1.47 & $1.77^{*}$ & -0.44 & -0.14 \\
\hline Gemmiza 9 x Sakha 94 & -5.31 & 0.61 & 1.40 & -2.62 & $-13.41^{\star *}$ \\
\hline Gemmiza 9 x Giza 168 & -0.23 & -0.29 & -0.06 & $-4.39^{* *}$ & $11.39^{* *}$ \\
\hline Gemmiza 9 x Jawahir-14 & -1.37 & 0.91 & $-2.05^{\star}$ & $-5.70^{* *}$ & $-16.40^{\star \star}$ \\
\hline Gemmiza 9 x Acsad 925 & -1.29 & -0.61 & $-2.77^{\star *}$ & $-16.23^{\star *}$ & $-7.27^{\star *}$ \\
\hline Gemmiza 9 x Bob white & -0.21 & $-3.66^{\star *}$ & 1.15 & -1.50 & $-10.77^{\star \star}$ \\
\hline Sakha 93 x Sakha 94 & $-6.36^{*}$ & 1.47 & $-2.33^{\star}$ & $-3.05^{\star}$ & $-7.96^{\star *}$ \\
\hline Sakha 93 x Giza 168 & -4.05 & 0.58 & $7.66^{* *}$ & $-5.15^{\star *}$ & $5.40^{*}$ \\
\hline Sakha $93 \times$ Jawahir-14 & -0.50 & $-4.13^{\star *}$ & 1.03 & $-7.38^{* *}$ & $-3.33^{*}$ \\
\hline Sakha 93x Acsad 925 & 1.06 & $-7.08^{\star *}$ & $-3.80^{* *}$ & $-4.17^{\star *}$ & $-14.55^{\star *}$ \\
\hline Sakha 93 x Bob white & 0.61 & $-6.49^{* *}$ & -1.50 & -1.79 & 1.40 \\
\hline Sakha 94 x Giza 168 & -4.98 & -0.87 & $-3.25^{\star \star}$ & 2.05 & -2.54 \\
\hline Sakha 94 x Jawahir-14 & 1.32 & 0.31 & 0.14 & -2.35 & $6.30^{* *}$ \\
\hline Sakha 94 x Acsad 925 & 0.23 & 0.31 & $-7.48^{* *}$ & $-6.05^{\star *}$ & $-17.31^{\star *}$ \\
\hline Sakha 94 x Bob white & -1.30 & -1.86 & -1.51 & $-5.55^{\star *}$ & $17.09^{* *}$ \\
\hline Giza 168 x Jawahir-14 & $-6.88^{*}$ & $-3.77^{\star *}$ & $-2.33^{*}$ & -0.66 & $-2.62^{*}$ \\
\hline Giza 168 x Acsad 925 & $-5.48^{*}$ & $-6.67^{* *}$ & -0.12 & $-3.32^{*}$ & $15.24^{\star *}$ \\
\hline Giza 168 x Bob white & -1.50 & $-4.93^{\star \star}$ & $-3.65^{\star \star}$ & $-9.64^{* *}$ & -3.25 \\
\hline Jawahir-14 x Acsad 925 & 4.98 & $-4.44^{\star *}$ & $-11.70^{* *}$ & 0.44 & $-23.46^{\star *}$ \\
\hline Jawahir-14 x Bob white & $-7.34^{*}$ & -0.95 & $-2.28^{*}$ & $-6.39^{* *}$ & $3.96^{\star *}$ \\
\hline Acsad $925 \times$ Bob white & -2.39 & 0.33 & $-5.71^{* *}$ & $-5.49^{\star *}$ & $-11.02^{* *}$ \\
\hline Mean & -1.90 & -1.89 & -1.78 & -4.25 & -3.49 \\
\hline
\end{tabular}

*and ${ }^{* *}$ indicate significance at 0.05 and 0.01 probability levels, respectively. 
Table 7. Estimates of general combining ability effects of the seven parents for days to $50 \%$ heading, days to maturity, flag leaf area, plant height and no. of spikes/plant traits

\begin{tabular}{|c|c|c|c|c|c|}
\hline Parents & $\begin{array}{l}\text { Days to } 50 \% \\
\text { heading }\end{array}$ & $\begin{array}{l}\text { Days to } \\
\text { maturity }\end{array}$ & $\begin{array}{c}\text { Flag leaf } \\
\text { area }\end{array}$ & $\begin{array}{l}\text { Plant } \\
\text { height }\end{array}$ & $\begin{array}{c}\text { No. of } \\
\text { spikes } \\
\text { per plant }\end{array}$ \\
\hline P1:Gemmiza 9 & $4.19^{\star \star}$ & $3.13^{* *}$ & $2.42^{* *}$ & $6.63^{* *}$ & $-1.10^{* *}$ \\
\hline P2:Sakha 93 & $-0.62^{\star *}$ & $-0.72^{\star *}$ & $5.52^{* *}$ & $0.97^{* *}$ & $0.35^{\star *}$ \\
\hline P3:Sakha 94 & $-1.1^{\star \star}$ & -0.13 & $-1.26^{\star *}$ & $3.27^{* *}$ & $0.46^{* *}$ \\
\hline P4:Giza 168 & $-1.84^{\star *}$ & $-0.76^{* *}$ & $2.16^{* *}$ & $4.15^{\star *}$ & -0.10 \\
\hline P5:Jawahir-14 & $-2.66^{\star \star}$ & $-3.02^{\star \star}$ & -0.06 & $-2.88^{\star *}$ & $1.34^{* *}$ \\
\hline P6:Acsad 925 & $1.53^{* *}$ & $1.42^{* *}$ & $-5.34^{\star *}$ & $-5.54^{* *}$ & $-2.44^{* *}$ \\
\hline P7: Bob white & $0.49^{* *}$ & 0.09 & $-3.45^{* *}$ & $-6.59^{* *}$ & $1.49^{* *}$ \\
\hline S.E(gi) & 0.09 & 0.07 & 0.13 & 0.13 & 0.10 \\
\hline LSD(gi-gj) 0.05 & 0.18 & 0.14 & 0.26 & 0.26 & 0.20 \\
\hline 0.01 & 0.24 & 0.19 & 0.35 & 0.35 & 0.27 \\
\hline
\end{tabular}

${ }^{*}$ and $^{* *}$ indicate significance at 0.05 and 0.01 levels, respectively.

Table 8. Estimates of general combining ability effects of the seven parents for spike length, no. of spikelets/spike, no. of kernels/spike, 1000-kernel weight and grain yield/plant traits

\begin{tabular}{|c|c|c|c|c|c|}
\hline Parents & $\begin{array}{l}\text { Spike } \\
\text { length }\end{array}$ & $\begin{array}{c}\text { No. of } \\
\text { spikelets } \\
\text { per spike }\end{array}$ & $\begin{array}{c}\text { No. of } \\
\text { kernels per } \\
\text { spike } \\
\end{array}$ & $\begin{array}{c}1000- \\
\text { kernel } \\
\text { weight }\end{array}$ & $\begin{array}{c}\text { Grain } \\
\text { yield per } \\
\text { plant }\end{array}$ \\
\hline P1:Gemmiza 9 & $0.38^{* *}$ & $0.37^{\star \star}$ & $2.50^{* *}$ & $-2.86^{\star \star}$ & $-3.83^{\star \star}$ \\
\hline P2:Sakha 93 & -0.03 & $0.54^{* *}$ & $-1.13^{\star *}$ & $-2.77^{\star *}$ & $-1.60^{\star *}$ \\
\hline P3:Sakha 94 & $-0.63^{* *}$ & $0.23^{\star *}$ & $2.94^{\star *}$ & $-0.34^{*}$ & $2.90^{\star *}$ \\
\hline P4:Giza 168 & $0.64^{* *}$ & $0.80^{\star *}$ & $-2.03^{* *}$ & $0.47^{* \star}$ & $-1.15^{\star *}$ \\
\hline P5:Jawahir-14 & $-0.41^{* *}$ & $-0.31^{* *}$ & $4.37^{* *}$ & $3.52^{* \star}$ & $8.69^{* *}$ \\
\hline P6:Acsad 925 & $-0.16^{*}$ & $-0.86^{* *}$ & $-5.50^{\star *}$ & $5.65^{\star *}$ & $-6.59^{\star *}$ \\
\hline P7: Bob white & $0.21^{* *}$ & $-0.78^{* *}$ & $-1.15^{\star *}$ & $-3.66^{* *}$ & $1.58^{\star *}$ \\
\hline S.E(gi) & 0.08 & 0.05 & 0.13 & 0.14 & 0.10 \\
\hline LSD(gi-gj) 0.05 & 0.16 & 0.10 & 0.26 & 0.28 & 0.20 \\
\hline 0.01 & 0.21 & 0.13 & 0.35 & 0.37 & 0.27 \\
\hline
\end{tabular}

${ }^{*}$ and $^{* *}$ indicate significance at 0.05 and 0.01 levels, respectively.

and Bob white parents for spike length trait, Gemmiza 9, Sakha 93, Sakha 94 and Giza 168 parents for number of spikelets per spike trait, Gemmiza 9, Sakha 94 and Jawahir-14 parents for number of kernels per spike trait, Giza 168, Jawahir-14 and Acsad 925 parents for 1000 grain weight trait, Sakha 94, Jawahir-14 and Bob white parents for grain yield per plant trait. This would indicated that the previous mentioned parental genotypes could be used in breeding programs for improving wheat productivity.

\section{II-Specific combining ability effects}

Specific combining ability effects for the studied traits are presented in Tables (9 and 10). For days to $50 \%$ heading trait, seven out of the studied twenty one wheat crosses (Gemmiza 9xSakha 93, Gemmiza 9xSakha 94, Gemmiza 9xGiza 168, Sakha 93xJawahir-14, Sakha 93xBob white, Giza 168xBob white and Acsad $925 \times$ Bob white) showed negative (desirable) and significant specific combining ability effects, which indicating tendency towards earliness.

Regarding days to maturity trait, eleven out of the studied twenty one wheat crosses (Gemmiza 9x Sakha 94, Gemmiza 9x Giza 168, Sakha 93x Sakha 94, Sakha 93xGiza 168, Sakha 93x Jawahir-14, Sakha 93xBob white, Sakha 94xAcsad 925, Giza 168x Acsad 925, Jawahir-14x Acsad 925, Jawahir-14xBob white and Acsad 925xBob white) exhibited negative (desirable) and significant specific combining ability effects, indicating tendency towards earliness. The results of flag leaf area trait 
Table 9. Estimates of specific combining ability effects of the 21 wheat crosses for days to $50 \%$ heading, days to maturity, flag leaf area, plant height and no. of spikes/plant traits

\begin{tabular}{|c|c|c|c|c|c|}
\hline Crosses & $\begin{array}{c}\text { Days to } 50 \% \\
\text { heading }\end{array}$ & $\begin{array}{l}\text { Days to } \\
\text { maturity }\end{array}$ & $\begin{array}{c}\text { Flag leaf } \\
\text { area }\end{array}$ & $\begin{array}{l}\text { Plant } \\
\text { height }\end{array}$ & $\begin{array}{c}\begin{array}{c}\text { No. of } \\
\text { spikes per } \\
\text { plant }\end{array} \\
\end{array}$ \\
\hline Gemmiza 9 x Sakha 93 & $-0.65^{\star}$ & 0.16 & 0.37 & $2.27^{\star \star}$ & 0.24 \\
\hline Gemmiza 9 x Sakha 94 & $-3.50^{\star *}$ & $-4.10^{* *}$ & -0.58 & $-1.66^{\star *}$ & -0.08 \\
\hline Gemmiza 9 x Giza 168 & $-1.43^{* *}$ & $-1.13^{* *}$ & -0.17 & $-1.03^{* *}$ & 0.05 \\
\hline Gemmiza 9 x Jawahir-14 & $2.06^{\star \star}$ & $3.12^{\star *}$ & $2.97^{\star *}$ & $0.80^{*}$ & 0.2 \\
\hline Gemmiza 9 x Acsad 925 & 0.2 & $1.34^{\star *}$ & 0.53 & $-3.43^{* *}$ & 0.3 \\
\hline Gemmiza 9 x Bob white & 0.24 & 0.01 & $-1.45^{\star *}$ & $2.12^{\star \star}$ & $-0.68^{*}$ \\
\hline Sakha 93 x Sakha 94 & $0.64^{*}$ & $-0.92^{* *}$ & $3.65^{\star *}$ & $1.03^{\star *}$ & -0.17 \\
\hline Sakha 93 x Giza 168 & $0.73^{\star *}$ & $-0.62^{* *}$ & $-0.96^{*}$ & 0.06 & -0.58 \\
\hline Sakha 93 x Jawahir-14 & $-2.13^{* *}$ & $-1.36^{\star \star}$ & $0.94^{*}$ & $-1.83^{\star \star}$ & -0.23 \\
\hline Sakha 93x Acsad 925 & 0.36 & 0.19 & $1.49^{* *}$ & $-2.55^{\star *}$ & $-0.70^{*}$ \\
\hline Sakha 93 x Bob white & $-0.61^{*}$ & $-0.81^{* *}$ & $1.14^{* *}$ & $-0.83^{*}$ & $0.87^{\star *}$ \\
\hline Sakha 94 x Giza 168 & $0.54^{*}$ & $0.45^{\star}$ & -0.31 & -0.26 & -0.35 \\
\hline Sakha 94 x Jawahir-14 & $2.02^{* *}$ & $0.71^{\star *}$ & $-1.17^{\star *}$ & -0.56 & 0.31 \\
\hline Sakha 94 x Acsad 925 & -0.16 & $-1.40^{* *}$ & 0.69 & $2.03^{* *}$ & 0.52 \\
\hline Sakha 94 x Bob white & -0.47 & -0.40 & $2.23^{\star *}$ & $1.38^{\star *}$ & $0.94^{\star *}$ \\
\hline Giza 168 x Jawahir-14 & $0.76^{\star *}$ & 0.34 & $-1.24^{\star *}$ & 0.57 & 0.15 \\
\hline Giza 168 x Acsad 925 & $-0.76^{\star *}$ & $-1.10^{* *}$ & $4.39^{* *}$ & $-0.9^{*}$ & $1.41^{\star *}$ \\
\hline Giza 168 x Bob white & $0.95^{\star \star}$ & $0.56^{\star *}$ & $3.27^{\star *}$ & $1.04^{\star \star}$ & 0.15 \\
\hline Jawahir-14 x Acsad 925 & $0.72^{* \star}$ & $-1.51^{\star *}$ & -0.18 & $0.79^{*}$ & $0.62^{*}$ \\
\hline Jawahir-14 x Bob white & 0.09 & $-0.51^{*}$ & $1.99^{* *}$ & $0.95^{\star}$ & 0.16 \\
\hline Acsad $925 \times$ Bob white & $-2.09^{* *}$ & $-0.95^{\star *}$ & -0.29 & $4.29^{* *}$ & -0.46 \\
\hline S.E(sij) & 0.26 & 0.21 & 0.38 & 0.38 & 0.29 \\
\hline LSD (sij-sik) 0.05 & 0.67 & 0.55 & 0.99 & 0.98 & 0.77 \\
\hline 0.01 & 0.85 & 0.69 & 1.25 & 1.24 & 0.97 \\
\hline LSD (sij-skl) 0.05 & 0.62 & 0.51 & 0.93 & 0.92 & 0.72 \\
\hline 0.01 & 0.78 & 0.65 & 1.17 & 1.16 & 0.91 \\
\hline
\end{tabular}

*and ${ }^{* *}$ indicate significance at 0.05 and 0.01 levels, respectively.

(Table 9) indicated that, positive and significant SCA effects were observed in only nine crosses out of the 21 studied crosses (Gemmiza 9x Sakha 93, Sakha 93xSakha 94 , Sakha 93xJawahir-14, Sakha 93xAcsad 925, Sakha 93xBob white, Sakha 94xBob white, Giza 168xAcsad 925, Giza 168xBob white and Jawahir-14xBob white). Therefore, these hybrids are considered as good F1-cross combinations for this trait. Concerning plant height trait, ten out of the studied twenty one wheat crosses (Gemmiza 9xSakha 93, Gemmiza 9xJawahir-14, Gemmiza 9xBob white, Sakha 93xSakha 94, Sakha 94xAcsad 925, Sakha 94xBob white, Giza 168xBob white, Jawahir-14xAcsad 925, Jawahir14xBob white and Acsad 925xBob white) exhibited positive and significant specific combining ability effects. Therefore, these crosses were considered as good cross combinations for this trait. These results were in a harmony with those obtained by Attia et al (2014); Raiyani et al (2015) and Ahmad et al (2017). Regarding No. of spikes per plant trait only four cross out of the 21 studied crosses (Sakha 93xBob white, Sakha 94xBob white, Giza 168x Acsad 925 and Jawahir-14x Acsad 925) exhibited positive and significant specific combining ability effects. For spike length trait, only two out of studied twenty one wheat crosses (Sakha 94xBob white and Jawahir-14xAcsad 925) showed positive and significant specific combining ability effects. With respect to number of spikelets per spike trait, only five out of twenty the studied one wheat crosses (Gemmiza 9xSakha 93, Gemmiza 9xJawahir-14, PxAcsad 925, Sakha 93x Sakha 94 and Sakha 94x Acsad 925) showed positive and significant specific combining ability effects. 
Table 10. Estimates of specific combining ability effects of the 21 wheat crosses for spike length, no. of spikelets/spike, no. of kernels/spike, 1000-kernel weight and grain yield/plant traits

\begin{tabular}{|c|c|c|c|c|c|}
\hline Crosses & $\begin{array}{l}\text { Spike } \\
\text { length }\end{array}$ & $\begin{array}{c}\text { No. of } \\
\text { spikelets } \\
\text { perspike }\end{array}$ & $\begin{array}{c}\text { No. of } \\
\text { kernels per } \\
\text { spike }\end{array}$ & $\begin{array}{c}1000- \\
\text { kernel } \\
\text { weight }\end{array}$ & $\begin{array}{c}\text { Grain } \\
\text { yield per } \\
\text { plant }\end{array}$ \\
\hline Gemmiza 9 x Sakha 93 & 0.26 & $0.38^{*}$ & $1.92^{\star *}$ & -0.02 & $0.76^{\star \star}$ \\
\hline Gemmiza 9 x Sakha 94 & 0.04 & -0.24 & -0.22 & 0.39 & -0.40 \\
\hline Gemmiza 9 x Giza 168 & 0.05 & 0.12 & $1.53^{\star *}$ & 0.46 & $1.38^{* *}$ \\
\hline Gemmiza 9 x Jawahir-14 & 0.32 & $0.36^{*}$ & $-1.88^{\star *}$ & $1.28^{* *}$ & 0.21 \\
\hline Gemmiza 9 x Acsad 925 & 0.08 & $0.58^{* *}$ & $3.08^{* *}$ & $-3.05^{\star *}$ & 0.52 \\
\hline Gemmiza $9 \times$ Bob white & -0.15 & -0.16 & $1.50^{\star *}$ & 0.44 & $-0.79^{*}$ \\
\hline Sakha 93 x Sakha 94 & -0.33 & $0.53^{* *}$ & 0.70 & 0.1 & $-0.95^{\star *}$ \\
\hline Sakha 93 x Giza 168 & -0.05 & 0.15 & $2.51^{* *}$ & 0.01 & $-0.63^{*}$ \\
\hline Sakha $93 \times$ Jawahir-14 & 0.16 & -0.21 & $4.07^{\star *}$ & 0.32 & $3.13^{* *}$ \\
\hline Sakha 93x Acsad 925 & 0.09 & $-0.33^{*}$ & $-1.26^{\star *}$ & $3.57^{* \star}$ & 0.19 \\
\hline Sakha $93 \times$ Bob white & 0.2 & -0.27 & $-1.50^{\star *}$ & $-1.21^{\star *}$ & 0.36 \\
\hline Sakha 94 x Giza 168 & 0.43 & 0.13 & $0.93^{*}$ & $0.97^{\star}$ & 0.25 \\
\hline Sakha 94 x Jawahir-14 & 0.06 & 0.04 & -0.68 & 0.5 & $2.42^{* *}$ \\
\hline Sakha 94 x Acsad 925 & 0.16 & $0.59^{* *}$ & $1.31^{* *}$ & 0.09 & $1.18^{* *}$ \\
\hline Sakha 94 x Bob white & $0.57^{*}$ & 0.05 & $1.31^{* *}$ & -0.14 & $3.53^{* *}$ \\
\hline Giza 168 x Jawahir-14 & -0.04 & 0 & $2.44^{* *}$ & 0.57 & $2.95^{\star *}$ \\
\hline Giza 168 x Acsad 925 & -0.11 & -0.12 & 0.46 & 0.81 & $4.98^{\star \star}$ \\
\hline Giza 168 x Bob white & 0.06 & 0.21 & $-2.01^{* *}$ & $-1.22^{\star *}$ & $-1.39^{\star *}$ \\
\hline Jawahir-14 x Acsad 925 & $0.50^{*}$ & $-0.41^{* *}$ & $-1.13^{\star \star}$ & -0.14 & 0.19 \\
\hline Jawahir-14 x Bob white & -0.41 & 0.25 & $1.60^{* *}$ & $1.73^{* *}$ & $2.81^{* *}$ \\
\hline Acsad $925 \times$ Bob white & -0.04 & 0.07 & 0.09 & $3.74^{* *}$ & 1.90 ** \\
\hline S.E(sij) & 0.23 & 0.15 & 0.39 & 0.42 & 0.3 \\
\hline LSD (sij-sik) 0.05 & 0.6 & 0.39 & 1.02 & 1.09 & 0.79 \\
\hline 0.01 & 0.76 & 0.49 & 1.29 & 1.38 & 1 \\
\hline LSD (sij-skl) 0.05 & 0.56 & 0.36 & 0.95 & 1.02 & 0.74 \\
\hline 0.01 & 0.71 & 0.46 & 1.21 & 1.29 & 0.94 \\
\hline
\end{tabular}

*and** indicate significance at 0.05 and 0.01 levels, respectively.

Regarding number of kernels per spike trait, only ten out of the studied twenty one wheat crosses (Gemmiza 9xSakha 93, Gemmiza 9xGiza 168, Gemmiza 9xAcsad 925, Gemmiza 9xBob white, Sakha 93x Giza 168, Sakha 93x Jawahir-14, Sakha 94x Giza 168, Sakha 94x Acsad 925, Sakha 94xBob white and Giza 168xJawahir-14) exhibited positive and significant specific combining ability effects. Therefore, these crosses were considered as good cross combinations for this trait. This results were in a harmony with those obtained by Jatoi et al (2012); Singh et al (2012); Attia et al (2014) and Raiyani et al (2015). Concerning 1000-kernel weight trait (Table 13), only five crosses out of the 21 studied crosses (Gemmiza 9xJawahir-14, Sakha 93xAcsad 925, Sakha 94xGiza 168, Jawahir-14xBob white and Acsad $925 \times$ Bob white) showed positive significant SCA effects, which indicating a tendency for heavier 1000-kernel weight. Similar results were obtained by many investigators such as Khodadadi et al (2012); Sadeghi et al (2012) and Attia et al (2014). Finally grain yield per plant trait (Table 9), only ten out of the studied twenty one wheat crosses (Gemmiza 9xSakha 93, Gemmiza 9xGiza 168, Sakha 93xJawahir-14, Sakha 94xJawahir-14, Sakha 94xAcsad 925, Sakha 94xBob white, Giza 168xJawahir-14, Giza 168xAcsad 925, Jawahir14xBob white and Acsad 925xBob white) showed positive and significant specific combining ability effects. Therefore, these crosses were considered as good cross combinations for this trait. These results were similar with the results of Attia et al (2014), Raiyani et al (2015) and Kumar et al (2017). 


\section{REFERENCES}

Ahmad, E., Akhtar, M., Badoni, S. and Jaiswal, J.P. 2017. Combining ability studies for seed yield related attributes and quality parameters in bread wheat (Triticum aestivum L.). J. of Genetics, Genomics \& Plant Breeding, 1(1), 21-27.

Attia, S.A.A., Nagwa R. Abed El-Hameid and $x$ Haiba, J.P. 2014. Heterosis, Combining Ability Analysis of Some Bread Wheat Crosses and the Genetic Relationship Among the Included Studied Cultivars. J. of Applied Sci. Research 9(10), 6394-6403.

Ismail. S.K.A. 2015. Heterosis and Combining Ability Analysis for yield and its Components in Bread Wheat (Triticum aestivum L.). Int. J. Curr. Microbiol. App. Sci., 4(8), 1-9.

Griffing, B. 1956. Concept of general and specific combining ability in relation to diallel crossing system. Aust. J. Biol. Sci., 9, 463 - 493.

Jatoi, W.A., Baloch, M.J., Khan, N.U., Kumbhar, M.B. and Keerio, M.I. 2012. Genetic analysis of physiological and yield traits under drought stress conditions in wheat. Sabrao J. of Breeding and Genetics 44(1), 9 -27.

Kalhoro, F.A., Rajpar, A.A., Kalhoro, S.A., Mahar, A., Ali, A., Otho, S.A., Soomro, R.N., Ali, F. and Baloch, Z.A. 2015. Heterosis and Combing Ability in $\mathrm{F}_{1}$ Population of Hexaploid Wheat (Triticum aestivum L.). American J. of Plant Sci., 6, 1011-1026.

Khaled, M.A. and Abd El-dayem, S.M. 2014. Combining ability analysis for grain yield and its attributes in bread wheat under stress and normal irrigation conditions. J. Plant Production, Mansoura Univ., 5(2), 255 -266.

Khodadadi, E., Aharizad, S., Sabzi, M. and Shahbazi, H. 2012. Combining ability analysis of bread quality in wheat. Annals of Biological Research, 3(5), 2464-2468.

Kumar. J., Singh, S.K., Singh, L., Kumar, M., Srivastava, M., Jagbir Singh and Arun Kumar 2017. Combining Ability Analysis for Yield and its Components in Bread Wheat (Triticum aestivum L.) under Abiotic Stress. Int. J. Curr. Microbiol. App. Sci., 6(3), 24-39.

Ljubičić, N., Petrović, S., Kostić, M., Dimitrijević, M., Hristov, N., K-Špika, A. and Jevtić, R. 2017. Diallel analysis of some important grain yield traits in bread wheat crosses. Turk J. Field Crops, 22(1), 1-7.

Patel, H.N. 2017. Combining ability analysis for yield and its components in bread wheat Electronic J. of Plant Breeding, 8(2), 404-408.

Raiyani, A.M., Patel, D.A., Kapadia, V.N., Boghara, M.C. and Sisara, H.C. 2015. Combining ability and gene action for different characters in bread wheat (Triticum aestivum L.) IQJLS, 10(4), 2159-2162.

Sadeghi, F., Dehghani, H., Najafian, G. and Aghaee, M. 2012. Genetic analysis of breadmaking quality attributes in hexaploid wheat (Triticum aestivum L.). Annals of Biological Research, 3(7), 3740-3749.

Shehzad, M., Hussain, S.B., Qureshi, M.K., Akbar, M., Javed, M., Imran, H.M. and Manzoor, S.A. 2015. Diallel cross analysis of plesiomorphic traits in Triticum aestivum L. genotypes. Genet. Mol. Res., 14(4), 13485-13495.

Singh. V., Krishna, R., Singh, S. and Vikram, P. 2012. Combining ability and heterosis analysis for yield traits in bread wheat (Triticum aestivum). Indian J. of Agric. Sci., 82(11), 916921.

Thomas, N., Marker, S., Lal, G. and Dayal, A. 2017. Study of heterosis for grain yield and its components in wheat (Triticum aestivum) over normal and heat stress condition. J. of Pharmacognosy and Phytochemistry 6(4), 824830.

Tiwari, R., Marker, S. and Meghawal 2017. Combining ability estimates for spike characters in $F_{1}$ hybrids developed through diallel crosses among macaroni wheat (Triticum durum Desf.) genotypes. J. of Pharmacognosy and Phytochemistry, 6(2), 237-241. 